\title{
Bahasa Visual dalam Sinetron Indonesia
}

Lucia Ratnaningdyah Setyowati

Jurusan Film dan Televisi, Fakultas Seni Media Rekam

Institut Seni Indonesia Yogyakarta

Jln. Parangtritis Km 6,5 Bantul, Yogyakarta 55001

Tlp.081804238189, E-mail: lucciferrs@yahoo.com

Volume 4 Nomor 1 , April 2017: 19-28

\begin{abstract}
ABSTRAK
Penelitian ini bertujuan untuk melakukan pemetaan dan menganalisiskekurangefektektivan penerapan bahasa visual sinetron Indonesia. Permasalahan utama yang menjadi fokus penelitian ini adalah bagaimana efektivitas penerapan bahasa visual dalam sinetron Indonesia. Sampel penelitian ini adalah dua episode dari setiap judul sinetron yang tayang di semua stasiun TV swasta selama dua minggu antara tanggal 26 September 2016 sampai dengan 10 Oktober 2016. Berdasarkan penelitian dapat disimpulkan bahwa penerapan bahasa visual dalam sinetron masih belum efektif. Bentuk ketidakefektifan ini antara lain masih lebih banyaknya penggunaan bahasa verbal baik dalam penyampaian pikiran tokoh maupun penguatan action yang seharusnya bisa lebih berbahasa visual. Hasil penelitian ini diharapkan menjadi masukan bagi para penulis scenario untuk meningkatkan kualitas program cerita televisi Indonesia.
\end{abstract}

Kata kunci: sinetron; bahasa visual; bahasa verbal; penguat action

\begin{abstract}
The Visual Language on Indonesian TV Series. This study aims to give a discourse and analysis on the ineffectiveness of the visual language application of Indonesian TV series. The main problem that becomes the focus of this research is how the effectiveness of the visual language application on Indonesian TV series. The samples of this study are two episodes of each title of the TV series that are broadcasted on all private TV stations for two weeks between September 26, 2016 until October 10, 2016. Based on the research, it can be concluded that the application of visual language on TV series is still not effective. A sample of this ineffectiveness is seen when there is still more verbal language usage both in the delivery of characters' thoughts and the strengthening of the action figures in which it should be focusing more on the language visually. The result of this study is expected to be the input for the scenario writers to improve the quality of the programs of Indonesian television story.
\end{abstract}

Keywords: TV series; visual languange; verbal language; action strengthening

\section{Pendahuluan}

Sinetron atau sinema elektronik adalah salah satu dari banyak jenis program yang ditayangkan televisi yang banyak digemari oleh masyarakat Indonesia. Program cerita televisi ini merupakan adaptasi dari program cerita radio 'soap opera', dan menjadi program yang fenomenal karena merupakan salah satu program favorit di televisi. Program ini kerap kali menduduki rating tertinggi dan seringkali diproduksi dalam jumlah episode yang sangat banyak karena mampu bertahan menyedot perhatian pemirsa. MS Ralie Siregar semasa menjadi Presiden Direktur RCTI mengatakan:

... karena sinetron adalah mata acara yang paling banyak menyerap jumlah pemirsa di layar televisi. Secara kuantitatif, frekuensi kehadiran sinetron di layar televisi nasional sendiri meningkat. Kewajiban stasiun televisi 
nasional untuk meningkatkan menampilkan produk lokal tampaknya cenderung diisi dengan menghadirkan sinetron. (Siregar, 2005)

Sayangnya, kegemilangan sinetron sebagai program cerita televisi diiringi serangkaian hujatan terhadapnya. Pertama, karena program ini dinilai merupakan program "murahan" dengan alur cerita yang diulur-ulur tangga dramatiknya demi kepentingan mempertahankan keberlanjutan eksistensinya di mata pemirsa. Kedua, program ini dinilai sebagai program yang kurang bagus dan tidak mencerdaskan karena selain sebab di atas juga karena ketidaklogisannya dalam menetapkan motivasi dan action dari para tokohnya. Bahkan yang lebih parah sinetron kerap dituding sebagai pemberi referensi tindakan jahat dan sadis di masyarakat. Pada akhirnya program ini dianggap sebagai tontonan para ibu-ibu yang tidak punya kerjaan (menganggur) atau bahkan para pembantu rumah tangga.

Program televisi menempatkan program cerita sebagai pengemban fungsi menghibur. Akan tetapi, oleh beberapa sebab sebagaimana telah disebutkan, banyak kalangan terpelajar dan kaum eksekutif lebih memilih memenuhi kebutuhan hiburannya dalam bentuk cerita ini melalui film bioskop. Lalu ketika film bioskop ditayangkan di televisi, film bioskop tayangan TV inilah yang kemudian menjadi pilihan kaum intelek daripada menonton program asli cerita televisi.

Secara format ada perbedaan antara kedua jenis fiksi tersebut atas konsekuensi sifat media masing-masing. Itu sebabnya ketika film bioskop ditayangkan di televisi sebenarnya terdapat kekurangan-kekurangan dalam beberapa hal teknis yang juga berpengaruh pada tataran estetis, seperti komposisi gambar (Wenerda, 2012). Akan tetapi, para penontonnya lebih memilih mengabaikan hal ini dan tetap menonton film bioskop di televisi daripada menonton sinetron yang tidak cerdas.

Sangat disayangkan jika kemudian beberapa kalangan menampik sinetron sebagai tontonannya di televisi karena sebenarnya program ini mempunyai posisi strategis sebagai media budaya khususnya untuk kepentingan transfer nilai yang efektif. Kemasan cerita yang membungkusnya ditambah kehebatan media televisi sebagai penyebar informasi dan pengaruh, pastinya menjadi modal yang potensial bagi sinetron untuk melakukan tugas-tugas sebagai media pendidikan, pewarisan nilai, dan sebagainya. Salah satu hasil penelitian menyatakan bahwa para wanita di Amerika menggunakan soap opera sebagai referensinya mengatasi persoalannya (Allen, 1985).

Ketika program-program cerita dalam negeri ditinggalkan sebagian penontonnya, anehnya program cerita dengan format kemasan sama, yaitu serial televisi dari luar negeri, malah digemari penonton dalam negeri. Setelah era telenovela dari Amerika Latin yang merajai pertelevisian Indonesia, kini orang ramai membicarakan sinema Asia dari "Meteor Garden" garapan Taiwan, sampai belakangan sinema Korea yang merajai pertelevisian Indonesia. Bukan hanya cerita modern seperti "Full House", bahkan cerita-cerita tradisional Korea berlatar belakang sejarah seperti "The Great Quen of Seondeok" pun mendapatkan penontonpenonton fanatik di negeri ini. Demam Korea di bidang cerita diiringi juga dengan tren group vokal yang disebut boy band dan girl band yang juga marak di Jepang.

Selain telenovela Amerika Latin, program cerita atau sinema asia, serial televisi dari negara Barat juga banyak diminati penonton Indonesia sedari dulu, sebut saja "Charli Angels" yang terkenal pada era tahun 1980-an, atau yang populer beberapa waktu lalu, "Prison Break", juga merebut tempat di hati pemirsa Indonesia.

Perlu dicermati mengapa masyarakat Indonesia menyukai serial-serial asing, tetapi mengganggap rendah serial produk Indonesia. Selain jalan cerita yang menarik, pilihan dialog, pengadeganan, dan karakterisasi merupakan beberapa aspek yang merebut hati pemirsa Indonesia, dan bahkan belakangan pilihan kostum dalam sinema Korea menjadi tren tersendiri di kalangan remaja dan masyarakat Indonesia. Lalu apa yang terdapat dalam program cerita televisi Indonesia sehingga penonton menyepelekannya?

Salah satu hal yang sering terjadi dalam program cerita televisi terutama sinetron adalah menampilkan action tokoh yang melakukan suatu hal sembari si tokoh mengucap kata-kata pemberi penjelasan dalam action tersebut yang sebenarnya 
sudah jelas. Hal ini menjadi faktor yang tidak menyamankan penonton, dan mengesankan tontonan tersebut seolah menganggap bodoh penontonnya karena makna action tersebut sebenarnya bisa djelaskan dari action itu sendiri tanpa perlu penjelasan verbal. Dengan kata lain, sinetron tidak mampu menyajikan gambar yang 'bicara' atau tidak mampu menggunakan bahasa visual secara efektif sehingga harus dibantu bahasa verbal.

Dalam penelitian saya sebelumnya, "Action Konflik dalam Sinetron Indonesia", antara lain didapat hasil bahwa action konflik dalam sinetron ternyata banyak diwujudkan dalam action yang cenderung menggunakan bahasa verbal daripada visual (Setyowati, 2009). Banyak hal ditandai menjadi penyebab terlalu verbalnya penyajian sinetron sebagai tontonan audiovisual. Posisinya sebagai bagian dari dunia industri sering menjadi dugaan utama dari semua keburukan penampilan sinetron. Diasumsikan bahwa sinetron dengan sengaja menyajikan tontonan tidak cerdas untuk meraih pangsa pasar masyarakat kebanyakan yang juga tidak cerdas. Juga konsekuensi dari keberadaannya sebagai produk ekonomis, dengan menekan biaya semurah-murahnya untuk dapat dijual sebanyak-banyaknya sehingga mendapat hasil sebesar-besarnya. Analisis penyebab lain adalah memang karena ketidakmampuan penyajinya untuk mengemas sinetron dengan lebih baik.

Alasan-alasan tersebut tidak bisa begitu saja dijadikan pembenaran bahwa program cerita di televisi Indonesia memang 'jelek' karena ternyata masyarakat Indonesia juga menggemari program cerita negara lain yang lebih "cerdas" sebagai program televisi. Di tempat asalnya tontonan itu juga disaksikan kebanyakan masyarakatnya dan menjadi sukses dan popular sehingga kemudian Indonesia pun mengimpornya.

Sampel penelitian ini adalah dua episode dari setiap judul sinetron yang tayang di semua TV swasta kurun waktu antara tanggal 26 September 2016 sampai dengan 10 Oktober 2016. Pengambilan data dilakukan dengan mengamati rekaman dan memasukkan kategori-kategori data dalam form tabel data. Kategori-kategori tersebut ditetapkan berdasar pengamatan awal pada kecenderungan jenis bahasa visual yang muncul dalam sinetron dengan tetap menyediakan ruang bagi kemungkinan kemunculan jenis yang lain. Kategori utama adalah pemilahan adegan dengan jenis: (a) bahasa visual tidak efektif: (1) sebagai penyampai pikiran tokoh (ditampilkan dalam dialog dan ditampilkan secara voice over); (2) sebagai penguat adegan (ditampilkan dalam dialog dan ditampilkan secara voice over); (3) sebagai tujuan lain-lain, bukan termasuk dua kategori di atas (ditampilkan dalam dialog dan ditampilkan secara voice over) dan (b) bahasa visual efektif.

Kajian seni aoudio visual dalam masyarakat urban di Indonesia sudah dilakukan oleh para peneliti terdahulu, antara lain penelitian retorik dan makna ideologis karya instalasi dalam film Opera Jawa yang dilakukan C. Budiman (2013); penelitian mengenai konstruksi urban pemenjaraan seksual hingga hegemoni maskulinitas dalam film Soekarno yang dilakukan oleh B. Kartika (2015); penelitian tentang pendidikan sebagai perekrut dalam komunitas terbayang dalam film Denias Senandung di Atas Awan yang dilakukan Karina Melati (2014); dan penelitian transformasi naskah lakon Macbeth karya William Shakespeare ke film Throne of Blood yang dilakukan Arinta Agustina (2016). Dari berbagai kajian ini fokus utamanya adalah film. Belum banyak dijumpai kajian bahasa visual sinetron. Dengan mempertimbangkan posisi televisi sebagai media pendidikan dan budaya yang strategis, fenomena sinetron sangat sayang jika dibiarkan. Sibuk mengutuk pengaruh budaya Barat, tetapi membiarkan tontonan Barat mendapat tempat di hati pemirsa televisi. Bahkan, sekarang demam Korea sudah merambah ke berbagai hal dalam kehidupan masyarakat seperti tren mode dan trend musik. Penyanyi dangdut Indonesia yang sedang naik daun pun merupakan penyanyi yang dikenal luas mempunyai genre penampilan baru, yaitu Korean style. Anak-anak dan remaja pun menjadi lebih bangga jika penampilan dan kecantikan mereka dipuji sebagai Korean style.

Dengan berbagai pertimbangan tersebut, makin terasa kebutuhan untuk meningkatkan kualitas program cerita televisi Indonesia. Tentu saja hal ini harus dilihat dari kecermatan memahami kekuatan media televisi sebagai media 
audiovisual yang memiliki kekuatan, terlebih pada kemampuannya menyajikan gambar atau visual. Untuk itulah penelitian mengenai bahasa visual sinetron ini masih relevan dilakukan.

\section{Hasil dan Pembahasan}

Populasi dari penelitian ini setiap minggunya sebenarnya terdapat 15 judul sinetron, tetapi karena ada kasus pergantian dua judul sinetron pada minggu kedua dalam penelitian ini total tercatat 17 judul sinetron dalam dua minggu pengambilan sampel tersebut. Dengan penetapan pengambilan sampel tersebut seharusnya didapat total sampel sejumlah 30 episode sinetron, tetapi ternyata terdapat kerusakan perekaman data minggu kedua pada sinetron Indosiar berjudul "Si Buta dari Lembah Hantu". Oleh karena itu, total sampel yang digunakan dalam penelitian ini menjadi 29 episode.

\begin{tabular}{|c|c|c|c|c|}
\hline No & Stasiun TV & Judul & Episode & Tanggal \\
\hline 1 & RCTI & Tukang Bubur Naik Haji & 854 & 26 September 2016 \\
\hline 2 & & & 861 & 3 Oktober 2016 \\
\hline 3 & & Anak-Anak Manusia & 89 & 27 September 2016 \\
\hline 4 & & & 94 & 4 Oktober 2016 \\
\hline 5 & & Putri nomer Satu & 8 & 30 Oktober 2016 \\
\hline 6 & & & 15 & 7 Oktober 2016 \\
\hline 7 & & Surat Kecil untuk Tuhan & 23 & 1 Oktober 2016 \\
\hline 8 & & & 30 & 8 Oktober 2016 \\
\hline 9 & SCTV & Pesantren Rock n Roll & 146 & 26 September 2016 \\
\hline 10 & & Emak Ijah Ingin ke Mekah & 85 & 27 September 2016 \\
\hline 11 & & & 91 & 4 Oktober 2016 \\
\hline 12 & & Si Cemong & 38 & 2 Oktober 2016 \\
\hline 13 & & & 45 & 9 Oktober 2016 \\
\hline 14 & & 3 Semprul Mengejar Surga & 80 & 2 Oktober 2016 \\
\hline 15 & & Cinta yang Sama & 1 & 3 Oktober 2016 \\
\hline 16 & & Bidadari Surga & 1 & 7 Oktober 2016 \\
\hline 17 & MNC TV & Cinta Itu Anugrah & 2 & 27 September 2016 \\
\hline 18 & & & 6 & 4 Oktober 2016 \\
\hline 19 & & Juna Cinta Juni & 2 & 27 September 2016 \\
\hline 20 & & & 11 & 8 Oktober 2016 \\
\hline 21 & & Raden Kian Santang & 480 & 3 Oktober 2016 \\
\hline 22 & & & 488 & 11 Oktober 2016 \\
\hline 23 & & Biru & 8 & 4 Oktober 2016 \\
\hline 24 & & & 14 & 10 Oktober 2016 \\
\hline 25 & & Gadjah Mada & 129 & 8 Oktober 2016 \\
\hline 26 & & & 130 & 9 Oktober 2016 \\
\hline 27 & Indosiar & Aku Bukan Anak Haram & 22 & 30 September 2016 \\
\hline 28 & & & 29 & 7 Oktober 2016 \\
\hline 29 & & Si Buta dari Lembah Hantu & 1 & 30 September 2016 \\
\hline
\end{tabular}


Tabel 2. Rekapitulasi data bahasa visual

\begin{tabular}{|c|c|c|c|c|c|c|c|c|c|}
\hline \multirow{3}{*}{ Sinetron } & \multirow{3}{*}{ Tgl } & \multirow{3}{*}{ Eps } & \multicolumn{6}{|c|}{ Bahasa Visual Inefektif } & \multirow{3}{*}{$\begin{array}{l}\text { Bahasa } \\
\text { Visual } \\
\text { Efektif }\end{array}$} \\
\hline & & & \multicolumn{2}{|c|}{ Pikiran } & \multicolumn{2}{|c|}{+ action } & \multicolumn{2}{|c|}{$\mathbf{L} \mathbf{L}$} & \\
\hline & & & D & VO & D & VO & D & VO & \\
\hline Tukang Bubur Naik Haji & $26 / 09 / 16$ & 854 & 2 & 2 & 2 & 0 & 0 & 0 & 0 \\
\hline Tukang Bubur Naik Haji & $03 / 10 / 16$ & 861 & 0 & 15 & 0 & 0 & 0 & 0 & 0 \\
\hline Anak-Anak Manusia & $27 / 09 / 16$ & 89 & 1 & 9 & 0 & 0 & 0 & 0 & 0 \\
\hline Anak-Anak Manusia & $04 / 10 / 16$ & 89 & 1 & 28 & 0 & 0 & 0 & 0 & 1 \\
\hline Putri Nomer Satu & $30 / 09 / 16$ & 8 & 2 & 9 & 1 & 1 & 0 & 0 & 2 \\
\hline Putri Nomer Satu & $07 / 07 / 16$ & 15 & 1 & 20 & 0 & 0 & 0 & 0 & 0 \\
\hline Surat Kecil untuk Tuhan & $01 / 10 / 16$ & 23 & 1 & 6 & 0 & 0 & 0 & 0 & 3 \\
\hline Surat Kecil untuk Tuhan & $08 / 10 / 16$ & 30 & 2 & 3 & 0 & 0 & 0 & 0 & 0 \\
\hline TOTAL RCTI & & & 10 & 92 & 3 & 1 & 0 & 0 & 6 \\
\hline Pesantren Rock n Roll & $26 / 09 / 16$ & 146 & 5 & 3 & 0 & 0 & 0 & 0 & 0 \\
\hline Emak Ijah Ingin ke Mekah & $27 / 09 / 16$ & 85 & 3 & 5 & 0 & 0 & 0 & 0 & 0 \\
\hline Emak Ijah Ingin ke Mekah & $04 / 10 / 16$ & 91 & 3 & 13 & 2 & 0 & 0 & 0 & 0 \\
\hline Si Cemong & $0 / 13 / 16$ & 38 & 1 & 3 & 2 & 0 & 0 & 0 & 1 \\
\hline Si Cemong & $09 / 10 / 16$ & 45 & 15 & 3 & 2 & 1 & 0 & 0 & 2 \\
\hline 3 Semprul Mengejar Surga & $02 / 10 / 16$ & 80 & 11 & 0 & 1 & & 1 & & 1 \\
\hline Cinta yang Sama & $03 / 10 / 16$ & 01 & 9 & 0 & 1 & 0 & 0 & 0 & 1 \\
\hline Bidadari Surga & $07 / 10 / 16$ & 01 & 1 & 2 & 0 & 0 & 0 & 0 & 0 \\
\hline TOTAL SCTV & & & 48 & 29 & 8 & 1 & 1 & 0 & 5 \\
\hline Cinta Itu Anugerah & $27 / 09 / 16$ & 02 & 4 & 3 & 7 & 0 & 0 & 0 & 3 \\
\hline Cinta Itu Anugerah & $04 / 10 / 16$ & 6 & 5 & 5 & 0 & 0 & 0 & 0 & 2 \\
\hline Juna Cinta Juni & $01 / 10 / 16$ & 5 & 2 & 10 & 0 & 0 & 0 & 0 & 1 \\
\hline Juna Cinta Juni & $08 / 10 / 16$ & 11 & 0 & 5 & 0 & 0 & 0 & 0 & 1 \\
\hline Raden Kian Santang & $03 / 10 / 16$ & 480 & 9 & 4 & 6 & 0 & 0 & 0 & 1 \\
\hline Raden Kian Santang & $11 / 10 / 16$ & 488 & 9 & 8 & 2 & 0 & 1 & 0 & 1 \\
\hline Biru & $04 / 10 / 16$ & 8 & 16 & 5 & 6 & 1 & 0 & 0 & 1 \\
\hline Biru & $10 / 10 / 16$ & 14 & 10 & 0 & 0 & 0 & 0 & 0 & 0 \\
\hline Gadjah Mada & $08 / 10 / 16$ & 129 & 1 & 3 & 0 & 0 & 0 & 0 & 0 \\
\hline Gadjah Mada & $09 / 10 / 16$ & 130 & 3 & 1 & 1 & 0 & 0 & 0 & 0 \\
\hline TOTAL MNCTV & & & 59 & 44 & 22 & 1 & 1 & 0 & 10 \\
\hline Aku Bukan Anak Haram & $30 / 09 / 16$ & 22 & 1 & 1 & 0 & 0 & 1 & 0 & 1 \\
\hline Aku Bukan Anak Haram & $07 / 10 / 16$ & 29 & 3 & 0 & 0 & 0 & 0 & 0 & 2 \\
\hline Si Buta dari Lembah Hantu & $30 / 09 / 16$ & 1 & 1 & 1 & 0 & 0 & 0 & 0 & 0 \\
\hline TOTAL INDOSIAR & & & 5 & 2 & 0 & 0 & 1 & 0 & 3 \\
\hline
\end{tabular}

Keterangan:

- Pikiran = penyampai pikiran

- Dialog = penguat dialog

- D = ditampilkan dalam dialog

- $\mathrm{VO}=$ ditampilkan secara voice over

- $L L=$ lain-lain 


\begin{tabular}{lcccccccc}
\hline \multicolumn{1}{c}{ Bahasa Visual Inefektif } & \multicolumn{2}{l}{ Bahasa } \\
Stasiun TV & \multicolumn{1}{c}{ Pikiran } & + action & \multicolumn{2}{l}{ L L } & \multicolumn{2}{l}{ Visual Total } \\
& D & VO & D & VO & D & VO & Efektif \\
& 10 & 92 & 3 & 1 & 0 & 0 & 6 & \\
\hline RCTI & 18 & 29 & 8 & 1 & 1 & 0 & 5 & \\
SCTV & 48 & & & & \\
MNCTV & 59 & 44 & 22 & 1 & 1 & 0 & 10 & \\
INDOSIAR & 5 & 2 & 0 & 0 & 1 & 0 & 3 & \\
Jumlah & 122 & 167 & 33 & 3 & 3 & 0 & 24 & \\
Total & & & & & & 328 & 24 & 352 \\
& & & & & & $93 \%$ & $7 \%$ & $100 \%$ \\
\hline
\end{tabular}

Tabel 3. Rekapitulasi bahasa visual per stasiun TV

Terlihat bahwa kemunculan bahasa visual efektif hanya sekitar 7\%, sedangkan bahasa visual yang tidak efektif sekitar $93 \%$ atau rasionya hanya sekitar 1:9. Ini menunjukkan bahwa jauh lebih banyak bahasa visual yang tidak efektif dalam sinetron atau dengan kata lain efektivitas penggunaan bahasa visualnya rendah.

Dari kemunculan bahasa visual yang tidak efektif tersebut sebaran terbanyak pada kategori penyampai pikiran dengan penyajian secara voice over disusul kategori penyampaian pikiran yang ditampilkan dalam dialog. Penggunaan bahasa visual yang tidak efektif sebagai penguat action masih muncul walaupun jauh lebih lebih sedikit daripada yang penggunaannya sebagai penyampai pikiran.

Banyaknya penggunaan bahasa visual tidak efektif sebagai penyampai pikiran menunjukkan bahwa sinetron masih kurang memanfaatkan kelebihan-kelebihan televisi sebagai media audiovisual yang sebenarnya bisa memvisualisasikan apa yang secara fisik (kasat mata) tidak tampak. Sinetron masih menyajikannya dengan terlalu verbal. Sinetron menyajikan penyampaian pikiran yang ditampilkan dengan bahasa verbal secara voice over dengan maksud menunjukkan orang berbicara dalam hati. Dalam kehidupan wajar orang lain (penonton televisi) seharusnya tidak mendengar suara hati orang lain (tokoh) seperti misalnya yang terdapat dalam sinetron RCTI "Putri Nomer Satu", niat seorang ibu yang ingin bertanya kepada dokter dan mencari data tentang pasien seharusnya tidak perlu didengar langsung oleh penonton, tetapi penonton bisa memahami niat tersebut lewat adegan visual action tokoh.

Sinetron juga menyajikan penyampaian pikiran dalam dialog yang dimaksudkan untuk menunjukkan orang berbicara sendiri dalam upaya supaya penonton tahu apa yang dipikirkan tokoh. Dalam kehidupan nyata tidak lazim dalam kondisi wajar orang mengatakan apa yang dipikirkannya kepada dirinya sendiri, seperti yang terdapat dalam sinetron "Putri Nomor Satu". Juga penyesalan seorang ibu yang mesti berbohong kepada putranya untuk sebuah tujuan yang baik, tidak perlu didengar dialognya oleh penonton karena hal itu harusnya ada di dalam hati. Setting realisme dalam sinetron menjadi sebuah setting realisme yang tidak wajar.

Menurut George R. Kernodle, drama televisi merupakan salah satu genre realisme, yaitu realisme intimacy (intimacy realism), sebuah genre realisme yang menandai kedekatan hubungan drama televisi dengan penontonnya:

"Intimacy was the key word of the new drama, the final development of the intimate realism had appeared late in the nineteenth century and had dominated most stage productions since. Not even the small theatres of stage realism were as intimate as the "theatre" of TV audience in their homes" (Kernodle, 1967)

Masih munculnya adegan ketidakefektifan berbahasa visual sebagai penguat action lebih menggambarkan ketidakmampuan sinetron mengelola action-action visualnya dan makin menjauhkannya dari setting realisme yang wajar karena terkesan berlebihan. Misalnya dalam Sinetron MNCTV "Biru", action Biru yang ingin menolong Aldo dengan action memunguti sobekansobekan baju Aldo dan berniat menyatukannya kembali tidak perlu diiringi dengan voice over yang menjelaskan apa yang sedang dan akan dilakukan atau dilihatnya.

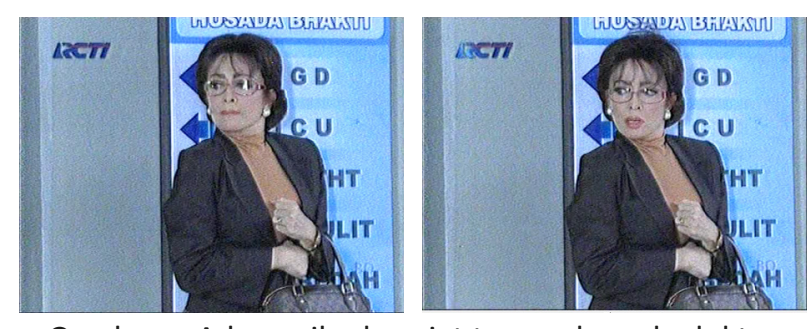

Gambar 1. Adegan ibu berniat tannya kepada dokter dalam sinetron "Putri Nomer Satu" 
Juga tokoh Arya dalam sinetron "Putri Nomer Satu" tidak perlu menjelaskan dengan dialog bahwa dia sedang melihat data dari panti asuhan sembari ber-action membuka-buka map yang sampulnya juga sudah ditulisi 'data panti asuhan'. Secara gamblang penonton televisi bisa menyaksikannya dalam gambar.

Selain beberapa contoh tersebut, berikut merupakan contoh lain ketidakefektifan bahasa visual dalam beberapa sinetron televisi di Indonesia. 1. Kategori penyampaian pikiran tokoh yang ditampilkan dalam dialog

Dalam sinetron "Surat Kecil untuk Tuhan" di RCTI ditemukan adanya penggunaan bahasa visual yang tidak efektif. Tokoh Morgan yang sedang menyetir mobil melihat Keke berjalan di tengah guyuran hujan sambil berkata, "Eh itu Keke kehujanan", kemudian menghampiri Keke untuk memberi tumpangan. Padahal tanpa perlu adanya dialog tersebut penonton juga tahu dalam adegan tersebut Keke kehujanan. Sinetron "Tukang Bubur Naik Haji” di RCTI juga demikian. Tokoh Robby berdialog dengan dirinya sendiri tentang langkah apa yang harus diambil agar karyawan dapat bekerja dengan profesional.

2. Kategori penyampaian pikiran tokoh yang ditampilkan dalam voice over

Salah satu adegan dalam sinetron "Juna Cinta Juni” di MNCTV menampilkan tiga tokoh dalam satu frame, yang salah satu tokohnya (pacar Juna) memiliki pikiran buruk terhadap Juni yang disuguhkan melalui voice over. Padahal dalam kenyataannya tidak ada orang yang bisa mendengar apa yang tengah dikatakan oleh orang lain dalam hati dan pikirannya.

3. Kategori penguat adegan yang ditampilkan dalam dialog

Sinetron "Cinta yang Sama" di SCTV dalam salah satu episode menampilkan adegan tiga remaja di dalam mobil, pengemudi mobil menabrak seorang pejalan kaki, setelah itu ia mengatakan "gue nabrak orang". Tanpa perlu ditambah dialog sudah sangat jelas bahwa pengemudi tersebut menabrak orang. Lewat ekspresi wajah kaget dan panik yang ditunjukkan oleh pengemudi dan teman-temannya dirasa
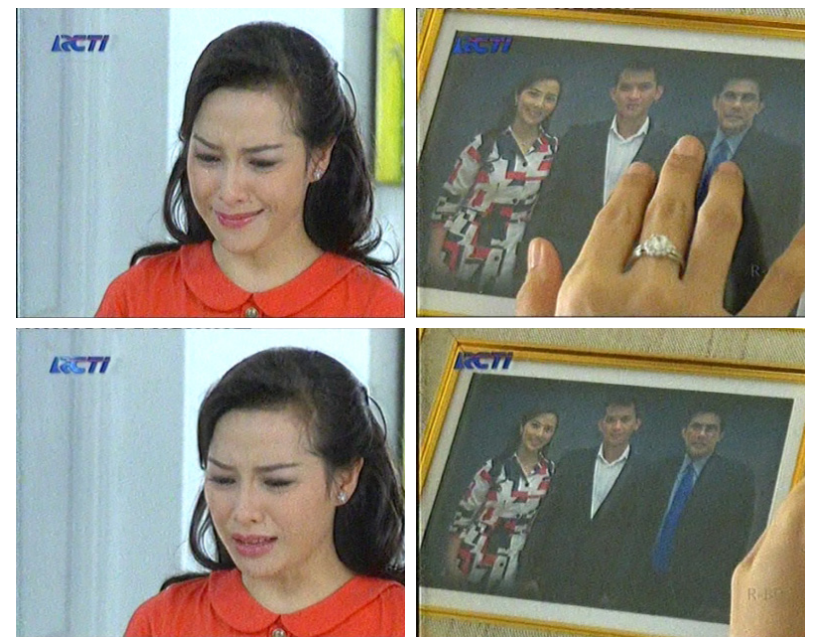

Gambar 2. Adegan ibu menyesal berbohong dalam sinetron "Putri Nomer Satu"
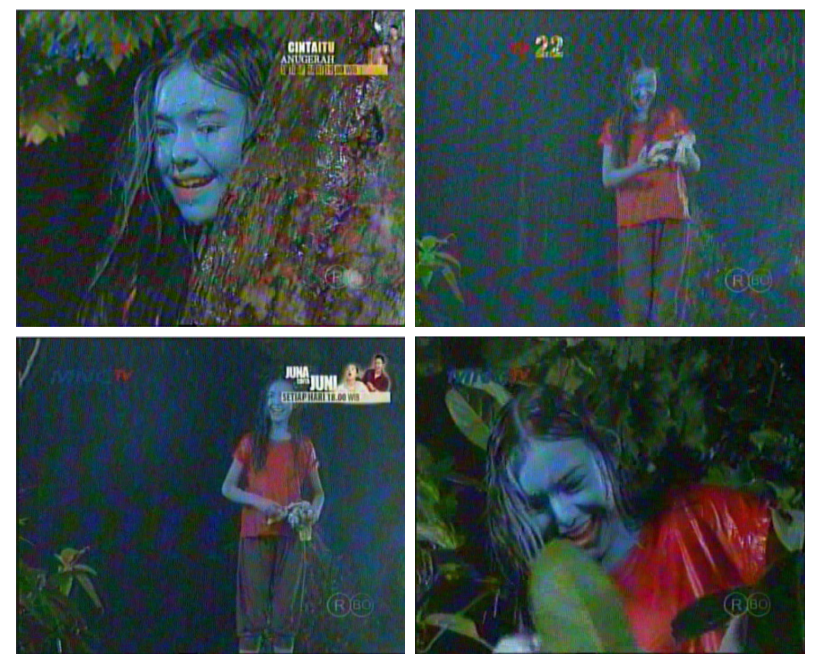

Gambar 3. Action Biru yang terlalu verbal dalam sinetron "Biru"
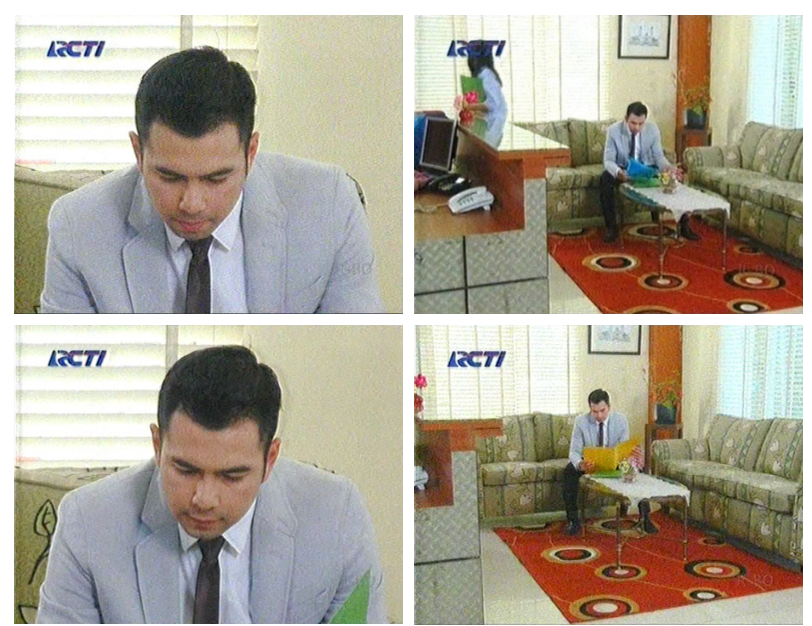

Gambar 4. Action Arya dalam sinetron "Putri Nomor Satu" yang menjelaskan hal yang sudah bisa diketahui penonton dari tulisan 
sudah cukup untuk menunjukkan ketegangan pada adegan tersebut. Begitu pula dengan sinetron "Emak Ijah Pengen ke Mekkah" yang tayang di SCTV. Dalam salah satu adegan seorang tokoh yang masuk rumah tanpa izin melihat dompet di atas meja dan mengambilnya dengan terlebih dahulu mengatakan, "Wah ada dompet, gua sikat aja”, yang sebenarnya dialog tersebut tidak dibutuhkan.

4. Kategori penguat adegan yang ditampilkan dalam voice over

Sinetron "Si Cemong" di SCTV menampilkan salah satu adegan seorang remaja bernama Cemong bersembunyi di belakang dua preman sambil berpikir mengerjainya. Pikiran tersebut diwujudkan melalui voice over "gue kerjain aja ah...”.

5. Kategori untuk tujuan lain-lain

Sinetron "3 Semprul Mengejar Surga” di SCTV dalam salah satu adegan seseorang yang dikeroyok massa menampilkan grafis seperti dalam komik. Padahal adegan tersebut sudah cukup didukung dengan penggunaan efek suara pukulan.

Sinetron "Aku Bukan Anak Haram" yang tayang di Indosiar terdapat sebuah adegan seorang pria yang memegang botol air keras menjelaskan kepada seorang wanita bahwa yang dipegang adalah air keras yang akan digunakan untuk mencelakai Ainun. padahal di botol tersebut tampak jelas terdapat tempelan stiker bergambar tengkorak yang biasa digunakan sebagai penanda zat kimia berbahaya, sambil menjelaskan secara verbal apa efek air keras tersebut.

Adegan-adegan tersebut tidak sesuai dengan apa yang dikatakan Louis Gianneti bahwa program audiovisual seperti serial televisi dan film seperti juga teater, sama-sama memakai kaidah-kaidah drama dalam materi ceritanya. Akan tetapi, media penyajian keduanya sangat berbeda. Teater disajikan dalam panggung, sedangkan film atau sinetron melalui media audiovisual layar film dan televisi. Hal ini mestinya mengusung perbedaan juga dalam performance-nya. Misalnya dalam hal suara atau dialog, Gianetti menyatakan sebagai berikut.
A major difference between stage dialogue and screen dialog is degree of density. One of the necessary convention of the live theatre is articulation: If something is bothering a character, we can usually assume that he or she will talk abaout the problem. The theater is a visual as well as aural medium, but in general the spoken word is dominant: We tend to hear before we see. If information is conveyed visually in the theatre, it must be larger than life, for most of the audience is too far from the stage to perceive visual nuances. The convention of articulation is necessary, therefore, to compensate for this visual loss. Like most artistic convention, stage dialogue is not usually realistic or natural, even in so-called realistic plays. In real life, people don't articulate their ideas and feelings with such precision. In movies, the convention of articulation can be relaxed. Since the close-up can show the most minute detail, verbal comment is often superfluous. This greater spatial flexibility means that film language doesn't have to carry the heavy burden of stage dialogue. In fact, since the image conveys most meanings dialogue in film can be as spare and realistic as it is in everyday life (Gianneti, 1993).
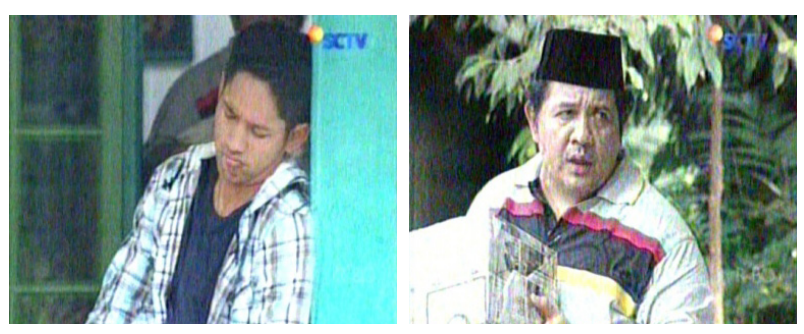

Gambar 5. Adegan berbahasa visual efektif dalam sinetron "Tiga Semprul Mengejar Surga"
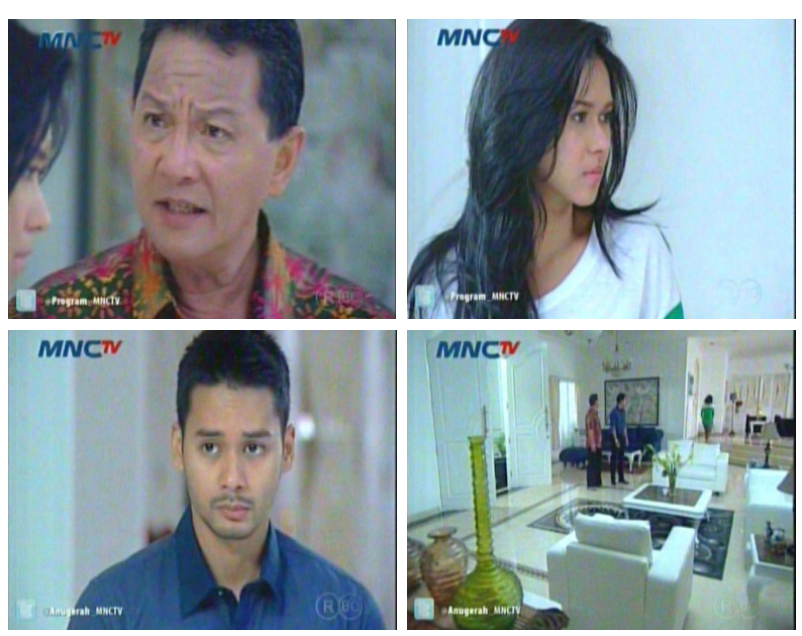

Gambar 6. Adegan efektif tanpa dialog dalam sinetron "Cinta Itu Anugerah" 
Beberapa sinetron menampilkan adegan yang dinilai cukup baik dalam menyajikan bahasa visual yang tergolong efektif. Seperti dalam sinetron "3 Semprul Mengejar Surga" di SCTV, dalam salah satu adegan seorang tokoh pria menunjukkan ekspresi resah karena galau. Tanpa adanya dialog ataupun voice over penonton dapat mengetahui suasana hati yang digambarkan oleh tokoh tersebut.

Hal yang hampir serupa juga ditemui dalam sinetron "Cinta Itu Anugerah" di MNCTV. Seorang tokoh ayah memarahi putrinya yang pergi tanpa pamit dari rumah. Tidak senang dengan perlakuan ayah dan suami yang terlalu mengatur, tokoh putri menunjukkan ekspresi wajah tidak senang dan melepaskan pegangan tangan tokoh ayah. Tanpa berkata apa pun tokoh putri meninggalkan setting. Rasa tidak senang tersebut cukup tergambar dengan baik melalui ekspresi wajah (akting) pemain. Tanpa ada tambahan bumbu dialog atau voice over, penonton juga akan paham.

\section{Simpulan}

Dari pemaparan dapat disimpulkan bahwa sinetron Indonesia masih diwarnai ketidakefektifan dalam penggunaan bahasa visualnya. Hal ini terlihat dari jauh lebih banyaknya adegan yang menggunakan bahasa visual tidak efektif dari pada yang efektif. Penggunaan bahasa visual yang tidak efektif berupa dominannya penggunaan bahasa verbal mengingkari kaidah televisi sebagai media audiovisual yang seharusnya lebih banyak menggunakan bahasa visual. Penggunaan bahasa verbal tersebut muncul dalam bentuk-bentuk berdasarkan urutan yang paling sering digunakan: (1) penggunaan bahasa verbal sebagai penyampai pemikiran tokoh dengan menggunakan teknik voice over yang menggambarkan tokoh sedang berbicara dalam hati; (2) penggunaan bahasa verbal sebagai penyampai pemikiran tokoh yang langsung ada dalam dialog (monolog) yang memperlihatkan tokoh berbicara sendiri; (3) penggunaan bahasa verbal sebagai penguat action yang biasanya ditampilkan dengan mengatakan secara langsung dalam dialog apa yang akan dilakukan oleh tokoh, atau sambil melakukan action tokoh tersebut mengatakan apa yang tengah dilakukannya yang kemudian berefek terlalu menjelaskan action yang mau atau sedang dilakukan; (4) penggunaan bahasa verbal sebagai penguat action dengan teknik voice over yang juga berefek terlalu menjelaskan niat action-nya, padahal action-nya juga sedang dilakukan.

Dari pengalaman melakukan penelitian ini bisa direkomendasikan beberapa saran berikut: (1) sebagai program bermedia audiovisual, sebaiknya sinetron tetap diupayakan untuk memaksimalkan penggunaaan bahasa visual yang efektif demi meningkatkan kualitasnya; (2) sebagai media yang terkait erat dengan budaya televisi tidak perlu ragu bahwa masyarakat tidak akan memahami jika lebih mengefektifkan bahasa visual karena justru televisi diiharapkan menjadi media yang mendukung budaya melek visual bagi masyarakat; (3) bagi peneliti secara teknis peralatan perekam sering mengalami kendala dengan ketidakpastian daya tangkap sinyal masing-masing alat sehingga perlu sekali dilakukan uji coba. Peralatan tv tuner tidak begitu bisa diandalkan untuk mengambil gambar dari antena langsung sehingga untuk bisa dipastikan dapat merekam dengan baik tv tuner tetap memerlukan pesawat televisi dengan tangkapan signal yang bagus dan tv tuner diperlakukan sebagai alat peng-capture gambar ke bentuk data digital untuk bisa diolah di komputer. Jadi, tv tuner tetap mengambil sumber dari output pesawat televisi.

\section{Ucapan Terima Kasih}

Ucapan terima kasih disampaikan kepada Lembaga Penelitian ISI Yogyakarta yang telah memberi dana untuk penelitian ini. Terima kasih juga disampaikan kepada para mahasiswa: Wahyudi, Leistar Adiguna, dan Maria Ulfa yang telah membantu proyek penelitian ini.

\section{Kepustakaan}

Agustina, A. (2016). Transformasi Naskah Lakon Macbeth (1603-1607) Karya William Shakespeare Ke Film Throne of Blood atau Kumonosu-Jo (1957) Karya Akira Kurosawa. Journal of Urban Society's Arts, 3(1), 1-9. doi:http://dx.doi.org/10.24821/ jousa.v3i1.1471 
Allen, R.C., (1985). Speaking of Soap Operas. Chapel Hill: The University of North Carolina Press.

Budiman, C. (2013). Retorik dan Makna Ideologis Karya Instalasi dalam Film Opera Jawa Garin Nugroho. RESITAL : JURNAL SENI PERTUNJUKAN, 14(1). doi:http://dx.doi. org/10.24821/resital.v14i1.390

Gianneti, L., (1993). Understanding Movies. 6th Ed., New Jersey: Prentice Hall.

Kartika, B. (2015). Mengapa Selalu Harus Perempuan: Suatu Konstruksi Urban Pemenjaraan Seksual Hingga Hegemoni Maskulinitas dalam Film Soekarno. Journal of Urban Society's Arts, 2(1), 35-54. doi:http://dx.doi.org/10.24821/jousa. v2i1.1268

Kernodle, G.R., (1967). Invitation To The Theatre. New York: Harcourt, Brace \& World, Inc.
Melati, K. (2014). Pendidikan sebagai Perekrut dalam Komunitas Terbayang: Analisa Wacana dalam Film Denias Senandung di Atas Awan. Journal of Urban Society's Arts, 1(2), 91-98. doi:http://dx.doi.org/10.24821/jousa. v1i2.790

Setyowati, L.R., (2009). "Action sebagai Visualisasi Konflik dalam Sinetron Indonesia." [Tesis] Sekolah Pascasarjana Universitas Gadjah Mada.

Siregar, A. ed., (2005). Sinetron Indonesia untuk Pasar dan Budaya. Yogyakarta: LP3Y.

Wenerda, I., (2012). "Analisis Perbedaan Aspek Rasio Film Dragonball Evolution Versi Layar Lebar dan Versi yang Ditayangkan sebagai Program Televisi Indonesia Ditinjau dari Implikasi pada Komposisi Gambarnya." [Skripsi] Jurusan Televisi, Fakultas Seni Media Rekam, ISI Yogyakarta. 